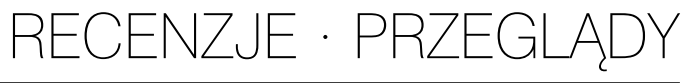

\title{
EUGENIUSZ SAKOWICZ, Dialog Kościota z islamem wedlug dokumentów soborowych i posoborowych (1963-1999), Warszawa 2000, 495 s.
}

Nie jest to pierwsza praca E. Sakowicza dotycząca problematyki dialogu chrześcijaństwa $\mathrm{z}$ islamem, jest on bowiem uczonym specjalizującym się w dziedzinie dialogu Kościoła z religiami pozachrześcijańskimi. Recenzowana tu publikacja jest jednak jedną z tych, które omawianą tematykę traktują bardzo obszernie, ale nie tylko $\mathrm{z}$ tego powodu zasługuje na poświęcenie jej uwagi. Autor podkreślając doniosłość zwołanego przez Jana XXIII i kontynuowanego przez Pawła VI soboru watykańskiego II odwołuje się do postulowanych idei konieczności prowadzenia dialogu $\mathrm{z}$ religiami niechrześcijańskimi, $\mathrm{w}$ tym $\mathrm{z}$ islamem. Niemałe znaczenie miał na to fakt wzrostu liczby wyznawców islamu na świecie, w tym także w Europie, spowodowanego między innymi rozwojem demograficznym oraz zjawiskiem migracji. Poza liczną populacją emigrantów z krajów Azji i Afryki coraz bardziej widoczne się stały społeczności konwertytów na islam, wywodzących się z ,etnicznych, rdzennych” (o ile można użyć takiego określenia) Europejczyków. Wszystko to rodzi przekonanie, że chrześcijanie muszą, a tym bardziej będą musieli w przyszłości porozumiewać się z muzułmańskimi sąsiadami na wielu płaszczyznach. Jest to tym istotniejsze, że opisując postawę samych muzułmanów wobec innych religii i ich wyznawców E. Sakowicz wyraźnie wskazuje na to, na co chrześcijanie powinni być przygotowani. Wyraża on w tym miejscu opinię, iż zwolennicy islamu są głęboko przekonani o tym, że już wkrótce ich religia stanie się dominującą, a następnie jedyną religią na świecie. Wynika to z wypowiedzi w mediach, rozpowszechnianych publikacjach, a także przeprowadzanych energicznych akcjach mających na celu doprowadzenie do konwersji na islam. Niektórzy ideolodzy islamu, według autora, docelowo dążą do islamizacji Stanów Zjednoczonych, co ma mieć wymiar niejako symboliczny, zważywszy na fakt ogłoszenia przez nich tego kraju największym wrogiem cywilizacji muzułmańskiej. Mamy tutaj więc także do czynienia z tym, co w ostatnich czasach często zwykło się określać (nie zawsze właściwie, jak sam autor przyznaje) jako nastroje fundamentalistyczne. Tej ostatniej „,etykietki” E. Sakowicz zresztą w swoim studium właściwie nie używa. Innym 
problemem z kolei jest spadek liczby wyznawców różnych odłamów religii chrześcijańskich, na co niemały wpływ mają także tendencje laicyzacyjne oraz sekularystyczne. Wynikającym z tego wnioskiem jest ostrzeżenie wiernych Kościoła katolickiego przed popadnięciem w złudną, fałszywą euforię i „zachłyśnięciem się” ideą dialogu oraz apel o realistyczne podejście do takiej idei.

Dowodząc słuszności takiego podejścia uczony już na samym początku podkreśla, że jedynie świadomość i wierność własnej tożsamości pozwalają stworzyć właściwe warunki do dialogu dla wszystkich zainteresowanych nim stron. O ile, jak już na to wskazano, wyznawcy islamu są przekonani o wyjątkowości i doskonałości swojej religii, o tyle po drugiej stronie również nie były nigdy odosobnione poglądy przypisujące chrześcijaństwu podobne właściwości, by tylko wspomnieć apologetykę (później teologię fundamentalną). Autor wydaje się przy tym być zdania, że to raczej muzułmanie zaszli dalej na tej drodze roszczeń. Komentując podejście muzułmanów do judaizmu i chrześcijaństwa podkreśla E. Sakowicz ich przekonanie o unieważnieniu prawa Mojżesza przez fakt dokonania się proroctwa Jezusa mającego to prawo zreformować. Konsekwencją tego zdarzenia z kolei było unieważnienie nakazów religii chrześcijańskiej, której zreformowanie miało być zadaniem objawienia przekazanemu Muhammadowi (Mahometowi). Siłą rzeczy takiemu podejściu towarzyszy głębokie przekonanie muzułmanów o bezcelowości istnienia innych, poza islamem, religii. O ile więc nie miałoby wielkiego sensu polemizowanie z opiniami autora na temat sytuacji religijnej w Arabii Saudyjskiej, o tyle warto być może było (na co jednak autor w tym miejscu się nie zdecydował) odnotować wyraźne zróżnicowanie w podejściu do mniejszości chrześcijańskich w poszczególnych krajach muzułmańskich, a zwłaszcza tych, w których te mniejszości odgrywają znaczącą rolę (dla przykładu można tu wskazać na Liban, Syrię, Egipt czy Irak). E. Sakowicz nie przemilcza jednakże i takich zjawisk, jak Bractwo św. Piusa X, działalność tego ugrupowania oraz jego postawę wobec współczesnej nauki Kościoła. Zwolennicy arcybiskupa M. Lefebvre'a są tutaj wymienieni w nawiązaniu do odrzucenia przez pewne kręgi katolików idei dialogu międzyreligijnego. Jak więc autor konstatuje, nie można być zdziwionym faktem, iż postulowany dialog jest niezwykle trudnym zadaniem. Jest on trudny tym bardziej, że często trzeba w tych relacjach uwzględniać jeszcze inny czynnik, trzecią, a zarazem najstarszą z monoteistycznych religii, mianowicie judaizm. Podkreślając fakt hermetycznego zamknięcia islamu na głoszone przez chrześcijaństwo prawdy oraz interpretacje uczony zwraca jednocześnie uwagę na to, że legalistyczny charakter religii Muhammada jest prawie identyczny 
z duchem nauki głoszonej przez wielu uczonych teologów żydowskich. W przeciwieństwie jednak do natury dialogu chrześcijańsko-judaistycznego, którego specyfika jest dość wyraźnie nakreślona, dialog chrześcijaństwa $\mathrm{z}$ islamem wciąż czeka na swoje dokładniejsze zdefiniowanie. Pierwszy z tych dialogów ma za zadanie między innymi odkrywanie własnych korzeni, czego przejawem jest wskazywanie na Żydów jako na „starszych braci w wierze". Dialog ten jest bardzo istotny także i dlatego, że widnieje on zawsze w tle dialogu chrześcijaństwa $\mathrm{z}$ islamem. W ten sposób autor stara się podkreślić bliskość wobec siebie trzech monoteistycznych wyznań. Za jeden z elementów utrudniających proces porozumienia autor uznaje brak zarówno w judaizmie, jak i w islamie rodzaju instytucji centralnej na wzór papieża jako autorytetu w kwestii wiary i moralności.

Studium E. Sakowicza przedstawia najpierw analizy poszczególnych dokumentów Kościoła dotyczących dialogu międzyreligijnego, zwłaszcza dialogu z islamem, zaczynając od omówienia sytuacji jeszcze z okresu przedsoborowego. Dla scharakteryzowania tej sytuacji przedstawia w tym miejscu instrukcję De motione oecumenica o ruchu ekumenicznym z 20 XII 1949. Dokument ten, co prawda, dotyczy regulacji zasady kontaktów katolików z niekatolikami, autor jednak nie widzi przeciwwskazań, aby nie odnieść go do relacji katolików z wyznawcami religii niechrześcijańskich. Równocześnie na mocy tej instrukcji za reprezentanta w dialogu między religiami uznana zostaje najwyższa władza Kościoła. Kolejny dokument, ogłoszona 11 IV 1963 encyklika Pacem in Terris Ojca Świętego Jana XXIII nie jest uznawana zasadniczo za dotyczącą dialogu międzyreligijnego, ale E. Sakowicz powołując się na zawarte w niej uwagi dotyczące odbiorców dochodzi do wniosku, że może ona być uznana za skierowaną także i do wyznawców religii niechrześcijańskich. W tym miejscu pracy autor daje wyraz swojej osobistej postawie wobec stereotypów odnoszących się do islamu pisząc, że religia ta, sama określając siebie jako „religię pokoju” jest często niesłusznie postrzegana jako „religia przemocy, wojny, a nawet terroryzmu".

Do jakiego stopnia wydarzeniem przełomowym także i dla dialogu między różnymi wyznaniami był sobór watykański II można się przekonać po zapoznaniu się z analizą dokumentów soborowych zaprezentowaną przez E. Sakowicza w następnej części publikacji. Znajdziemy tu omówienie w porządku chronologicznym poszczególnych konstytucji, dekretów i deklaracji, począwszy od uchwalonej w dniu 4 XII 1963 r. Konstytucji o liturgii świętej Sacrosanctum Concilium, poprzez inne doniosłej wagi dokumenty, na uchwalonej w dniu 7 XII 1965 r. Konstytucji duszpasterskiej o Kościele w świecie współczesnym Gaudium et spes kończąc. W pierw- 
szej Konstytucji zwraca uwagę czytelnika przypomnienie zasady inkulturacji oraz tzw. dialogu religijnego doświadczenia. Najważniejszy natomiast dokument Vaticanum II, Konstytucja dogmatyczna o Kościele Lumen gentium (21 XI 1964) poświęca swoje znaczące fragmenty określeniu postaw wobec wyznawców judaizmu oraz islamu, akcentując jednocześnie misję prowadzenia dialogu przez Kościół. Odniesienia do kształtowania postaw członków wspólnoty Kościoła katolickiego widać także i w innych dokumentach, w których przewija się również idea wzajemnego wzbogacania się, lepszego poznawania prawdy objawionej, własnej odnowy i wprowadzania w życie ekumenizmu. Jednym ze środków prowadzących do tego celu jest umożliwianie klerykom uczestnictwa w spotkaniach i modlitwach międzyreligijnych oraz poznawanie innych religii. Według E. Sakowicza szczególne miejsce dla dialogu międzyreligijnego w perspektywie soborowej ma Deklaracja o stosunku Kościoła do religii niechrześcijańskich Nostra aetate ( 28 X 1965), przede wszystkim dlatego, że zaznajamia z genezą i rozwojem pojęcia dialogu, kładąc nacisk na braterstwo ludzi wynikające z miłości Boga do nich, a także dlatego, iż akceptuje elementy prawdy zawarte w niechrześcijańskich tradycjach religijnych. Jest poza tym zauważalny w niej szacunek dla tych religii, a także ukierunkowanie na dialog dalekosiężny, nie ograniczający się jedynie do osiągnięcia doraźnych celów. W swoich rozważaniach autor nie mógł oczywiście pominąć Konstytucji dogmatycznej o Objawieniu Bożym Dei Verbum, ogłoszonej w dniu 18 XI 1965, zwłaszcza w tych fragmentach, które dotyczą problematyki rozpowszechniania Pisma Świętego i udostępniania go wyznawcom innych religii, nie mówiąc już o samym Objawieniu, jego naturze, sposobach przekazywania oraz interpretacji, a także niezwykle ważnej roli Tradycji. Stanowi to jednocześnie dla E. Sakowicza okazję do wysunięcia bardzo trafnego postulatu przeprowadzenia badań porównawczych nad problematyką Tradycji w chrześcijaństwie i sunny w islamie, połączonych ze studiami nad Pismem Świętym w życiu Kościoła oraz rolą Koranu w życiu wspólnoty muzułmańskiej.

Poza tymi oraz kilku innymi dokumentami soborowymi autor w dalszej części pracy przechodzi do omówienia problematyki dialogu międzyreligijnego i dialogu z islamem w nauczaniu papieży Pawła VI oraz Jana Pawła II. Jak wiele w tej dziedzinie uczynił pierwszy z nich można się przekonać po zaznajomieniu się z analizami jego listów apostolskich, encyklik, adhortacji i konstytucji, a także innych dokumentów, przemówień, homilii oraz katechez. Co jest warte podkreślenia w tym miejscu to fakt podjęcia przez Pawła VI wyzwań soboru watykańskiego II w odniesieniu do dialogu międzyreligijnego oraz otwarcie się tego papieża na tradycje nie- 
chrześcijańskie. Niewątpliwie znaczącym wydarzeniem tego okresu było również ustanowienie Sekretariatu dla Niechrześcijan. W świetle tych faktów można także lepiej zrozumieć i docenić rolę i dokonania papieża Jana Pawła II w zakresie dialogu między religiami, a zwłaszcza między chrześcijaństwem a islamem. Jest to widoczne w wielu ogłoszonych przez niego dokumentach, począwszy od encykliki Redemptor hominis (4 III 1979), gdzie mowa jest o znaczeniu dialogu $\mathrm{z}$ religiami niechrześcijańskimi dla uświadomienia sobie przez Kościół swojej własnej istoty, tradycji oraz zadań. E. Sakowicz akcentuje tutaj również osiągnięcia Ojca Świętego Jana Pawła II w rozwinięciu teologicznych uzasadnień dialogu interreligijnego, ich wpływu na praktykę prowadzenia tego dialogu. Częstotliwość, z jaką papież ten zwraca się w swoich wypowiedziach do wyznawców islamu świadczy dobitnie o randze, jaką przykłada on do porozumienia z nimi.

Osobną część pracy stanowi to, co autor określił jako „metodyczną refleksję na temat istoty i genezy dialogu Kościoła z islamem”. Ta część studium jest potraktowana szczegółowo, a zaczyna się od przedstawienia pojęcia dialogu, jego genezy, przejawów, partnerów dialogu, warunków jego prowadzenia a także form, celów mu przyświecających oraz przeszkód w jego realizowaniu. Ma to niebagatelne znaczenie nie tylko dla kompozycji samego opracowania, ale przede wszystkim dla właściwego zrozumienia tego, co stanowi istotę islamu w jego sferze doktrynalno-teologicznej. Znaleźć tutaj można ciekawe uwagi na temat przejawów synkretyzmu w różnych religiach, a także roli dialogu w kształtowaniu ducha tolerancji, wzajemnego zrozumienia i poszanowania. Co najmniej tak samo ciekawe są rozważania dotyczące natury Boga w islamie oraz sposobu Jego widzenia w dokumentach Kościoła, objawienia Bożego w Koranie i rozumienia tego objawienia przez autorów dokumentów Kościoła. Jak wiadomo, zarówno chrześcijaństwo, jak islam prezentują różny sposób rozumienia boskiego objawienia. Jako przykład podaje tutaj autor podejście do modlitwy, w chrześcijaństwie rozumianej często jako rozmowa z Bogiem, a w islamie jako Jego adoracja. Podobnie ma się sytuacja w przypadku różnego rozumienia przez Magisterium Kościoła oraz islam proroków, tzw. „rzeczy ostatecznych”, Jezusa i Jego Matki, a także kultu Boga, czego dowodem jest analiza dokonana w następnej części pracy.

Reasumując należy stwierdzić, że czytelnik interesujący się problematyką poruszaną w omawianej publikacji otrzymał niezwykle ważną, starannie opracowaną pozycję. Trudno jest tak obszerną pracę omówić nie stosując z konieczności pewnych skrótów myślowych, jako że wykorzystane w niej zostały wszystkie najważniejsze źródła oraz opracowania, tak krajowe, jak i obce. Za dużą jej zaletę trzeba uznać to, że nawet zawarte w niej polemicz- 
ne opinie mają charakter bardzo inspirujący. Wydaje się, że korzyści z pracy mogą wynieść zarówno ci, którzy patrzą na islam z punktu widzenia chrześcijaństwa (zwłaszcza katolicyzmu), jak i ci, którzy będą chcieli przyjrzeć się pewnym aspektom chrześcijaństwa wychodząc z punktu widzenia islamu. Niewątpliwą zasługą badacza jest wskazanie na te dokumenty Kościoła, które dotychczas nie były uważane za dotyczące przynajmniej w częśsi problematyki dialogu interreligijnego, w tym dialogu $\mathrm{z}$ islamem, a które w wyniku analizy E. Sakowicza za takie zostaną z pewnością uznane. Dołączona bogata bibliografia literatury przedmiotu, wymieniająca liczne prace znanych uczonych, by wspomnieć tylko W. Chrostowskiego, M. Czajkowskiego, J. Urbana, Ł. Kamykowskiego, J. Daneckiego, M. M. Dziekana, a także wiele opublikowanych wcześniej przez samego autora pozwala na wyrobienie sobie poglądu na wagę poruszanych w opracowaniu zagadnień. Wnioski naukowe wypływające $\mathrm{z}$ analiz autora wydają się być istotnym głosem $\mathrm{w}$ dialogu między chrześcijaństwem a islamem, którego obraz przedstawiony w publikacji uznać wypada za rzeczowy i obiektywny.

Kraków

ANDRZEJ BARTCZAK 